\title{
清酒熟度の迅速評価法と新規な劣化防止 技術の開発
}

近年, 食材や健康食品などの機能性の指標として抗酸化能が取り上げられ, 酒類や発酵食品の抗酸化性を 目，耳にする機会が増えています。これまで抗酸化能の測定は化学的な分析手法によることが一般的でした が, 熟成・劣化過程で生ずる微弱な発光を高感度な光電法によって測定する方法が開発され, 公的機関でも 採用されつつあるようです。この手法をいち早く酒類の熟成・劣化の評価に取り入れ，応用への道を開いた 著者に解説をいただきました。

\section{岡本竹己・渡邊英憲・齋藤高弘}

\section{1. はじめに}

最近の清酒の品質向上は著しいものがあり, 特に各 鑑評会の一般公開や製造技術研究会においてきき酒す る出品酒は, 入賞の有無に関わらずすばらしい酒質の ものばかりである。これは各蔵元において清酒製造に 関わる方々の酒造りにかける熱意，努力と，それを支 える酵母を中心とする酒造関連微生物開発や装置の進 歩が大きく貢献している。一方，市販酒に目を向ける と, 貯蔵時あるいは流通時の管理に起因すると考えら れる品質変化 (劣化) が生じてしまったと感じられる 高級酒が見受けられ，残念に感じることが少なくない。

清酒上槽後の貯蔵中の変化のメカニズムに関しては これまで多くの研究が行われてきているが, 醉造酒で ある清酒中には数百種類の成分が含まれていると考え られており，これらが複雑に関与する熟成，劣化に関 しては明らかになっていないことが多く，その評価の ほとんどは，最終的に熟練した人の官能による判断に 依存しているのが現状である。

我々は，これらの多くの成分を含む清酒の熟成や劣 化の変化を，網羅的，客観的に，そして簡易，かつ迅
速に評価する方法として, 食品の酸化劣化や抗酸化能 を総量で捉える手法としての化学発光法に着目し検討 を行ってきた。本手法は, 物質が励起状態から基底状 態に移行する際に光を放つ現象を応用しており, 微量 な測定対象物を光量として測定できることが報告され ており ${ }^{1-2)}$, 酸化劣化と強い関連のある食品, 生体組 織, 無機·有機化合物, そして高分子材料の劣化·老 化の測定など，幅広い分野で利用，検討が行われてい る。食品分野に関しては, 焙煎ゴマ油の保存に伴う品 質劣化判定 ${ }^{3)}$, 米の品質劣化の評価 ${ }^{4)}$ などがあり, そ れぞれ既存の手法に比べ簡便で迅速な測定を可能とし ている。

本文では，筆者らが取り組んできた「清酒の熟成・ 抗酸化特性の把握と迅速評価技術の開発」, および本 手法により確認した生酛系清酒の抗酸化性の高さを利 用した「新規な清酒劣化防止技術の開発」について解 説する。

\section{2. 化学発光による清酒の劣化，抗酸化性の評価}

化学発光による酸化劣化の測定原理概略を第 1 図に 示す。本測定法は, 酸化生成物であるヒドロペルオキ

Developments of Rapid Analysis of Sake Maturation and a New Prevention Method for Deterioration Takemi Окамото (Industrial Technology Center of Tochigi Prefecture, Food Technology Division) Hidenori Watanabe (Watanabe Sake Brewing Co. , Ltd)

Takahiro SAito (Faculty of Agriculture, Utsunomiya University) 
シドの分解により発生する極めて微弱な発光を, 高感 度の光電子増倍管を用いて検出，計測することにより， 酸化劣化度を定量的に評価する方法である。酸化反応 を網羅的に捉える手法であり，清酒の劣化は酸化に起 因する部分も多く含まれると考えられることから，本 方法による劣化度評価が可能ではないかと考え検討を 行った。

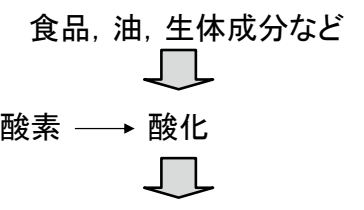

酸化物（ヒドロペルオキシド:ROOH）の発生
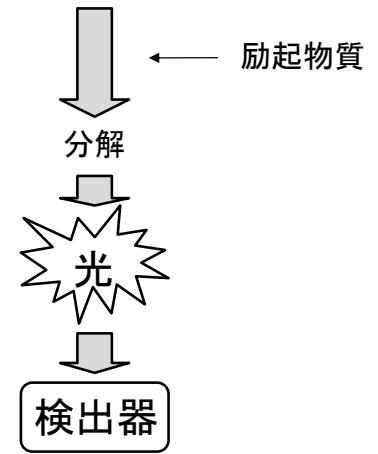

第 1 図化学発光による酸化物の測定原理

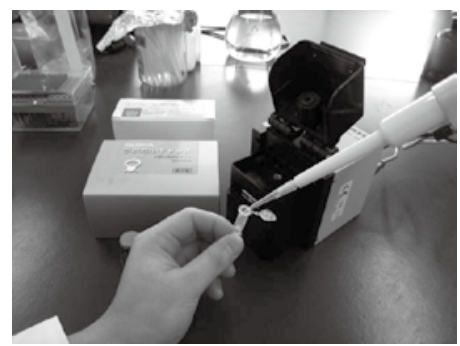

(1)イクロチューブに試料を入れる

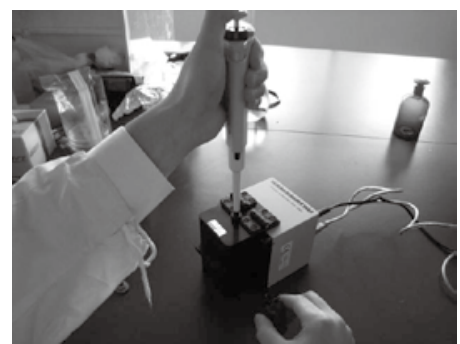

(3)測定機器上部からピペットを挿 入し試薬を分注する
現在我々が測定に用いている装置の操作手順を写真 に示す。マイクロチューブに入れた試料を装置にセッ 卜後, 完全に遮光した装置内（浜松ホトニクス C9692）で試薬を混合し, 発生した微弱な発光を PC に取り込むものであり，簡便な操作性と短時間で測定 が行える事が大きな長所と考えている。ここで用いた 発光系は, 沉用的な 3 種類の試薬を用い, 常温におい て非常に高い発光強度を持つものであり, TrautzSchorign 反応を応用したものである。

本手法の劣化度評価法としての有効性確認のため, 純米酒を透明瓶に入れ蛍光灯照射下 $50^{\circ} \mathrm{C} に て$ 強制劣 化させた場合の経時変化について, XYZ 系微弱発光 の X 発光 $(\text { 過酸化性 })^{5)}$ と劣化度評価法である TBA 法 $^{6-8)}$ との比較を行った (第2 図)。試験には製造口 ットの異なる 2 種類の純米酒を供した（純米吟醸酒, 精米歩合 55\%，セルレニン耐性酵母使用）（特別純米 酒，精米歩合 $60 \%$, K1001 使用)。TBA 法はアミノ カルボニル反応中間生成物である $3 \mathrm{DG}$ と反応し赤色 色素を生成する TBA（2 チオバルビッール酸）を利 用した清酒劣化指標である。

本結果より，TBA 法との間には高い相関関係が認 められ, 化学発光法が清酒の劣化度測定法として有効

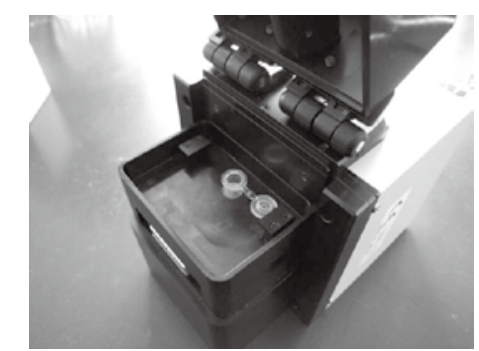

(2)測定機器にマイクロチューブを 設置する

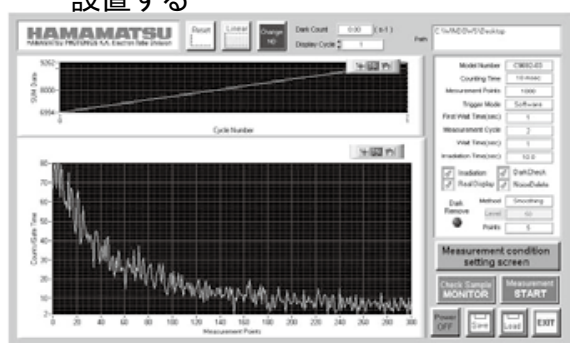

(4)測定機器に接続したPCから 発光量を測定する

写真 化学発光測定操作の流れ 
であることが確認できた。また，私共はセルレニン耐 性を付与したカプロン酸エチル高生産酵母による清酒 の酸化由来と考えられる特異的な劣化を, 化学発光法 で捉えられることを確認しており ${ }^{9-11)}$ ，今回の結果で 純米吟醉酒の X 発光值が純米酒と比較し高くなった 要因と考えている。
本装置は, 試薬を選択することにより簡易かつ迅速 に抗酸化性の評価を行うことが可能であることから， 次に化学発光の熟度評価法への利用の可能性について 確認を行うため, XYZ 系微弱発光の $Y$ 発光（抗酸化 性 $)^{12)}$ と, 清酒の熟度指標である DPPH 消去能による 抗酸化性測定法 ${ }^{13)}$ との比較を行った。

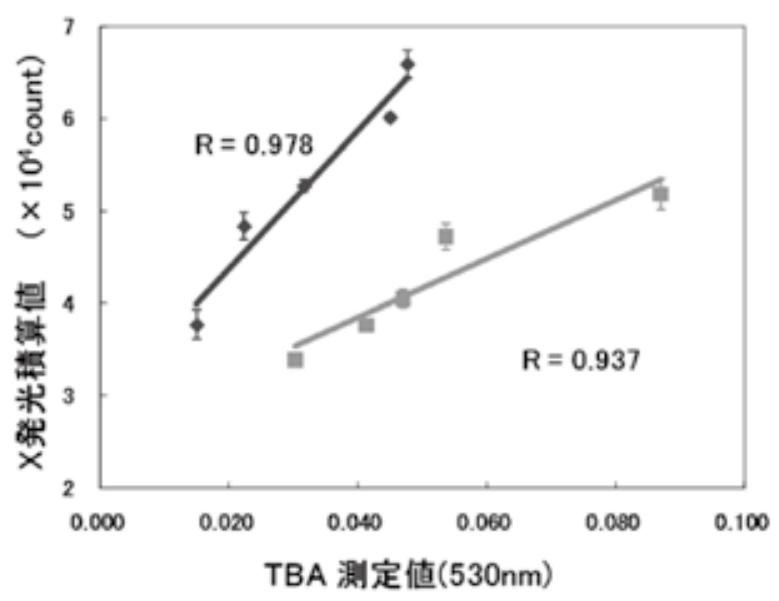

第 2 図 化学発光 $(X$ 発光) と TBA 測定值の関係 試料は透明瓶に入れ蛍光灯照射下 $50^{\circ} \mathrm{C}$

にて強制劣化させた

各数字は保存日数

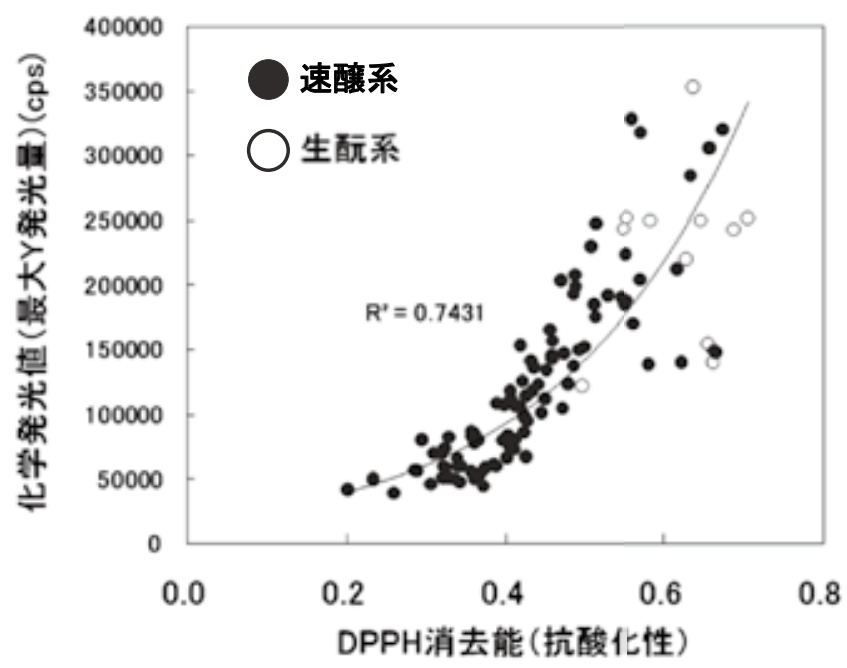

第 3 図 $D P P H$ 消去能 (抗酸化性) と化学発光 $(Y$ 発光) の関係 初吞み切り検酒時の清酒 (23 企業, 101 点) 
上槽後, 貯蔵途中での熟度評価を行う機会である初 吞み切り検酒時（平成 19 年 8 月実施）に, 栃木県内 の酒造メーカー 23 社から集められた H18BY 産の清 酒試料 101 点 (吟醉酒系, 生酒は除く) について, Y 発光法と DPPH 消去能の比較を行った結果を第 3 図 に示す。

ばらつきはあるものの, 両測定法には相関関係が見 いだされ，化学発光法の熟度評価法としての有効性が 示唆された。また, 第 3 図の右上に生酛系酒母の抗酸 化性が高いことが示されており興味深い。

以上から，同一装置で簡易に複数の情報を得ること が出来ることが明らかとなり, 化学発光法が製造現場 に扔ける熟成, 出荷管理において, 人の官能を補完す る有効なツールになり得ると考えられる。

\section{3. 新規な劣化防止技術の開発}

第 3 図の考察で述べたとおり，興味ある結果として 生酛系（山廃も含む）が高い抗酸化性を示す傾向があ ることが明らかとなった。生酛系酒母による清酒は, 幅のある味や押し味を特徵としている。その複雑な香 味は, 乳酸菌などの生酛系独特の微生物の働きにより 造り出されていると考えられ，その特異的な特性につ

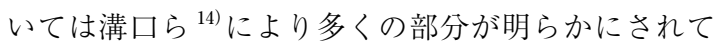
いる。また, 生配系清酒は貯蔵, 流通時に酒質が崩れ 難い，ある程度熟成させたものがおいしい等，速醉系 清酒と熟成経過が異なるとの話を酒造関係者から聞く ことも多い。

そこで筆者らは, 生酛の抗酸化性の高さに着目し, 本特性の劣化防止技術への応用の可能性について引き
続き検討を行った。

乳酸菌による発酵生産物が抗酸化能力を持つことは 広く知られており, 生酛系清酒の抗酸化性には乳酸菌 の代謝が関与しているものと推察し, 第 4 図の方法に より䤑造用乳酸を用いず培養乳酸菌添加により製造し た酒母を使用した清酒（五百万石，精米歩合 $60 \% ， 9$ 号系酵母使用）を小仕込により製造した。同一原料に より速醸酒母で製造したものを比較対照とし， $30^{\circ} \mathrm{C}$ 暗 所において保存試験を行い, $\mathrm{NaClO}$ 発光法を用い過 酸化物増加量による劣化の進み方の比較を行い第 5 図 に示した。本発光は, 過酸化物質に $\mathrm{NaClO}$ を添加す ることにより一重項酸素を主体とする発光種が生まれ ることに基づいており，X発光と同様に酸化により生 じる多種のヒドロペルオキシドを捉えており，X発光 の数十倍の発光量があり, かつ短時間（1 分以内）で の測定が可能である。我々は, 本発光が清酒の劣化に 伴い増加する 3-DG, 熟成に伴い減少する DPPH 法に よる抗酸化性と高い相関を持つことを確認している ${ }^{15)}$ 。

なお，本試験では市販の Lactobacillus Sakei を䡘工 キス（精米歩合 95\%）で培養した乳酸菌培養液を, 高温糖化液に対し $0.5 \%$ 添加し, 対照は通常通り醉造 用乳酸添加（乳酸菌無添加）仕込みとしたが, 得られ た清酒の一般成分は第 5 図のとおりほぼ同じであった。

本結果より, 培養乳酸菌添加により製造した清酒は, 速醸酒母による清酒と比較し, 酸化に由来すると考え られる発光量増加が抑えられる傾向が示され, 実験室 レベルの小仕込において, 生酛系清酒は酸化劣化し難 い可能性があることを確認することができた。

高温糖化による米の溶解、殺菌<smiles>C1CCCCC1</smiles>

培養乳酸菌を添加し、増殖·代謝による酸度上昇 （雑菌污染リスクの少ない安全な酵母培養環境の調整）

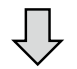

酵母添加

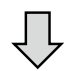

通常の酒母と同様の操作後仕込みに用いる

第 4 図高温糖化乳酸菌添加酒母の製造方法 


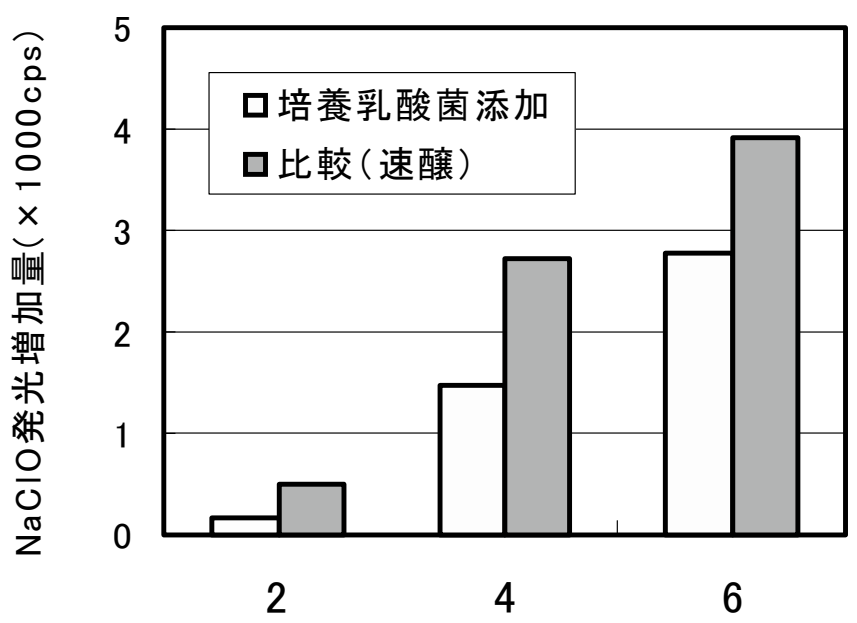

保存期間 (weeks at $30^{\circ} \mathrm{C}$ )

第 5 図試作清酒の加速劣化試験結果

一般成分 (日本酒度, アルコール分, 酸度,

アミノ酸度)は次のと打り

培養乳酸菌添加：+ 2, $17.6 \%, 2.7,2.2$

比較 (速醸) : $+1,17.9 \%, 2.5,2.0$

\section{4. 実地製造試験}

製造現場における同様の清酒製造の可能性について, 渡邊酒造(侏）（酒銘：旭興）にて実地製造試験を実施し た。

まず，過去にこのような手法がなかったか調べた結 果，明治後期に発案された「醴酛（あまざけもと）」 という方法が存在した ${ }^{16)}$ 。本法は $55^{\circ} \mathrm{C}$ で糖化した糖 化液に乳酸菌を添加し，乳酸が十分生成された後，酵 母を添加し酒母として用いる方法であり，我々が試み ようとしていた手法とほぼ同様であった。それらの中 の「二段式酸基醴酛」を参考にしたが，文献通りでは 乳酸生成までに時間がかかり過ぎるので，雑菌污染の リスク回避のため速やかな乳酸菌増殖による酸の生成, $\mathrm{pH}$ 低下を目的として第 6 図に示した手順で実施した。 乳酸菌（Lactobacillus Sakei）の培養条件予備試験に より，高温糖化後のボーメが $11 〜 13$, 靝歩合 $50 \%$ 程 度が速やかな酸度上昇と官能的にも満足ゆく品質のも のが得られることを確認した ${ }^{17)}$ 。仕込配合を第 1 表, 酒母経過を第 7 図, 醪経過を第 8 図に示した。

酒母, 醪とも経過は順調であり上槽時の酒質も満足

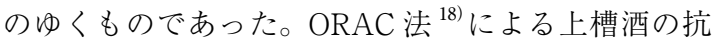
酸化性は, Trolox 換算で $3.45 \mathrm{mg} / 100 \mathrm{ml}$ で, 同社の同 規格生酛酒 $(3.30 \mathrm{mg} / 100 \mathrm{ml})$ と同様の数值であり, 同規格速醸清酒 $(2.68 \mathrm{mg} / 100 \mathrm{ml})$ よりも高い数值と なった ${ }^{19)}$ 。ORAC 法は活性酸素種を発生させ，それ によって分解される蛍光物質の蛍光強度を測定し, こ の反応系に抗酸化物質が共存すると蛍光強度の減少速 度が遅延する原理を用いたものである。

上槽酒は生酛系の特徵を弱く感じるものの, 暗番に てきき酒を行ったところ生酛系と速䁔系の中間程度の 酒質との評価が多かった。速醸酒母により製造したほ ぼ同規格のものを比較対照とし, $30^{\circ} \mathrm{C}$ 暗所にて保存し 経時的に $\mathrm{NaClO}$ 法により劣化度の測定を行った結果 を第 9 図に示す。比較用速醉酒の試験開始時の発光值 は, 乳酸菌添加酒母に比べ低いものの, 保存中に経時 的に発光值が増加し, 25 日保存後では試験開始時の 1.57 倍の数值を示した。一方, 乳酸菌添加酒母のもの は, 25 日保存後においても発光量の増加は起らず, 酸化劣化がほとんど生じていないと考えられ，蔵にお ける実地スケールの製造においても, 乳酸菌添加によ る本法により製造された清酒は酸化劣化が起こりにく 
蒸米・米麦・水を入れ $55^{\circ} \mathrm{C} て ゙$ 糖化（Beが低いもの）

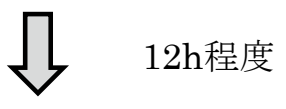

$30{ }^{\circ} \mathrm{C}$ 品温を落とし乳酸菌を添加

$$
\text { 凹 } 3 \text { days }
$$

酸が 3 程度出たところで酵母を添加

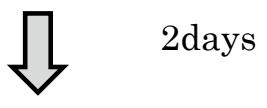

再度，蒸米・米麹・水を入れ $55^{\circ} \mathrm{C}$ で糖化

（Beが高いもの）を添加する

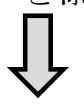

通常の高温糖化酛の経過，使用。

第 6 図 二段式酸基醴酛を参考とした酒母育成法

\begin{tabular}{|c|c|c|c|c|c|c|c|c|c|c|c|c|c|c|c|c|c|c|}
\hline 時間 & 9:30 & 9:40 & 18:30 & 19:30 & $19: 40$ & & & & $19: 00$ & & $6: 00$ & $21: 00$ & & & & & & \\
\hline 操作 & $\begin{array}{l}\text { 水 } \\
\text { 麹 }\end{array}$ & $\begin{array}{l}\text { 仕 } \\
\text { 込 } \\
\text { み }\end{array}$ & $\begin{array}{l}\text { お } \\
\text { 湯 } \\
\text { 投 } \\
\text { 入 }\end{array}$ & $\begin{array}{l}\text { 水 } \\
\text { 投 } \\
\text { 入 }\end{array}$ & \begin{tabular}{|l} 
乳 \\
酸 \\
菌 \\
添 \\
加
\end{tabular} & & & & $\begin{array}{l}\text { 酵 } \\
\text { 每 } \\
\text { 添 } \\
\text { 加 }\end{array}$ & & & $\begin{array}{l}\text { 後 } \\
\text { 段 } \\
\text { 添 } \\
\text { 加 }\end{array}$ & $\begin{array}{l}\text { 分 } \\
\text { け }\end{array}$ & $\begin{array}{l}\text { 枯 } \\
\text { ら } \\
\text { L }\end{array}$ & & & $\rightarrow$ & $\begin{array}{l}\text { 使 } \\
\text { 用 }\end{array}$ \\
\hline 品温 & 48.7 & 54.5 & \begin{tabular}{|l|}
62.2 \\
\end{tabular} & 35.1 & 35 & 30 & 30 & 30 & 30 & 30 & 30 & 29.8 & 30.3 & 13.9 & 8.3 & 7.2 & 6.9 & \begin{tabular}{|l|}
6.9 \\
\end{tabular} \\
\hline $\mathrm{Be}$ & & & & & 11.3 & & 12.2 & 12.5 & 12.5 & 12.5 & 9.5 & 13.5 & 10.3 & 7.5 & & 6.2 & 5.8 & 5.5 \\
\hline 総酸 & & & & & & & 1.6 & \begin{tabular}{|l|}
2.3 \\
\end{tabular} & 3.5 & 4 & 6.5 & 4.9 & \begin{tabular}{|l|}
5.3 \\
\end{tabular} & \begin{tabular}{|l|}
6.5 \\
\end{tabular} & & 6.7 & \begin{tabular}{|l|}
6.7 \\
\end{tabular} & 6.55 \\
\hline アミノ酸 & & & & & & & & & 4.1 & & 3.5 & 2.8 & 2.8 & & & & 2.4 & 2.7 \\
\hline Alc & & & & & & & & & & & & & & & & & 10.2 & 10.5 \\
\hline 酵母数 & & & & & & & & & & & & & & & & $3 \times 10^{8}$ & & \\
\hline
\end{tabular}

第 7 図 酒母経過

雄町，精米歩合 55\%， K701

第 1 表 酒母仕込配合

\begin{tabular}{|c|c|c|c|}
\hline & 前段 & 後段 & 計 \\
\hline 総米 (kg) & 10 & 18 & 28 \\
\hline 蒸米 (kg) & 5 & 12 & 17 \\
\hline 掼米 $(\mathrm{kg})$ & 5 & 8 & 13 \\
\hline 汲水 $(\ell)$ & $\begin{aligned} & (\text { 水 } 22 \ell) \\
30 \quad & (\text { 沸騰水 } 2 \ell) \\
& (\text { 水 } 6 \ell)\end{aligned}$ & $\begin{array}{c}\text { (水 } 16 \ell \text { ) } \\
20 \\
(\text { 水 } 4 \ell \text { ) }\end{array}$ & 50 \\
\hline
\end{tabular}




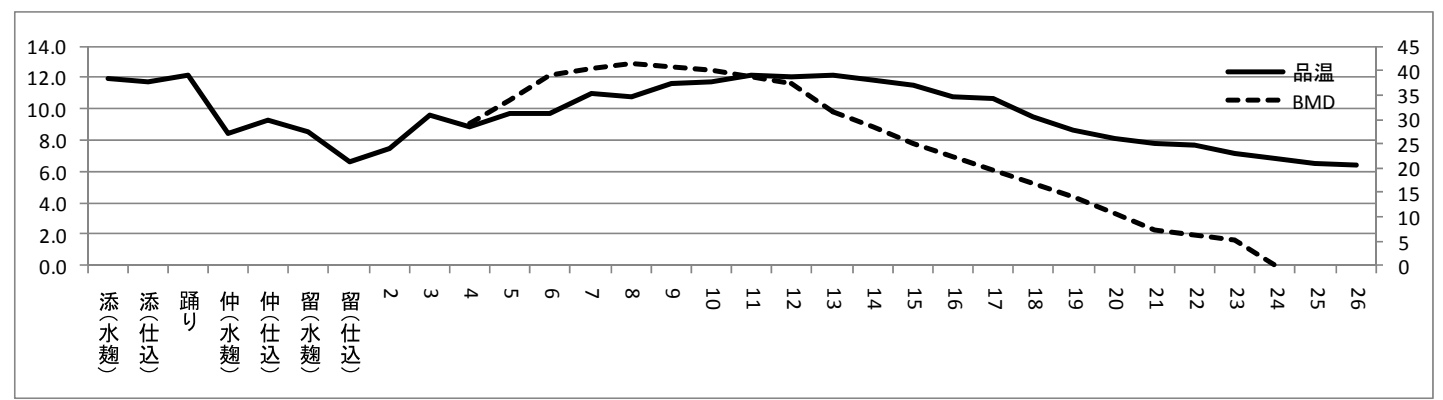

\begin{tabular}{|c|c|c|c|c|c|c|c|c|c|c|c|c|c|c|c|c|c|c|c|c|c|c|c|c|c|c|c|c|c|c|c|c|}
\hline & & 添 & 踊 & $\begin{array}{l}\text { 冰 } \\
\text { 邀) }\end{array}$ & 仲 & (水趣) & 留 & 2 & 3 & 4 & 5 & 6 & 7 & 8 & 9 & 10 & 11 & 12 & 13 & 14 & 15 & 16 & 17 & 18 & 19 & 20 & 21 & 22 & 23 & 24 & 25 & 26 \\
\hline 品温 & 11.9 & 11.7 & 12.1 & 8.4 & 9.3 & 8.5 & 6.6 & 7.5 & 9.6 & 8.9 & 9.7 & 9.7 & 11.01 & 10.81 & 11.6 & 11.7 & 12.2 & 12.0 & 12.11 & 11.81 & 11.51 & 10.81 & 10.79 & 9.5 & 8.68 & 8.1 & 7.8 & 7.7 & 7.2 & 6.8 & 6.5 & 6.4 \\
\hline アルコール & & & & & & & & & & & & & & & & & & 12.6 & 13.9 & & 14.4 & & 15.5 & & 16.2 & & 16.9 & & 16.8 & & 17.3 & 17.3 \\
\hline 日本酒度 & & & 10.8 & & & & & & & 7.3 & & 6.5 & & 5.2 & & 4 & & 3.1 & -24 & & -17 & & -12 & & -7.5 & & -3.5 & & -2.2 & & +1 & +3.3 \\
\hline 酸 & & & 2.2 & & & & & & & 9.5 & & 1.3 & & 1.5 & & 1.7 & & 1.7 & 1.6 & & 1.65 & & 1.7 & & 1.6 & & 1.6 & & 1.55 & & 1.55 & 1.5 \\
\hline アミノ酸 & & & & & & & & & & 0.2 & & 0.3 & & 0.35 & & 0.4 & & 0.6 & 0.65 & & 0.75 & & 0.85 & & 1 & & 1 & & 1 & & 1 & 1.15 \\
\hline
\end{tabular}

第 8 図醪経過

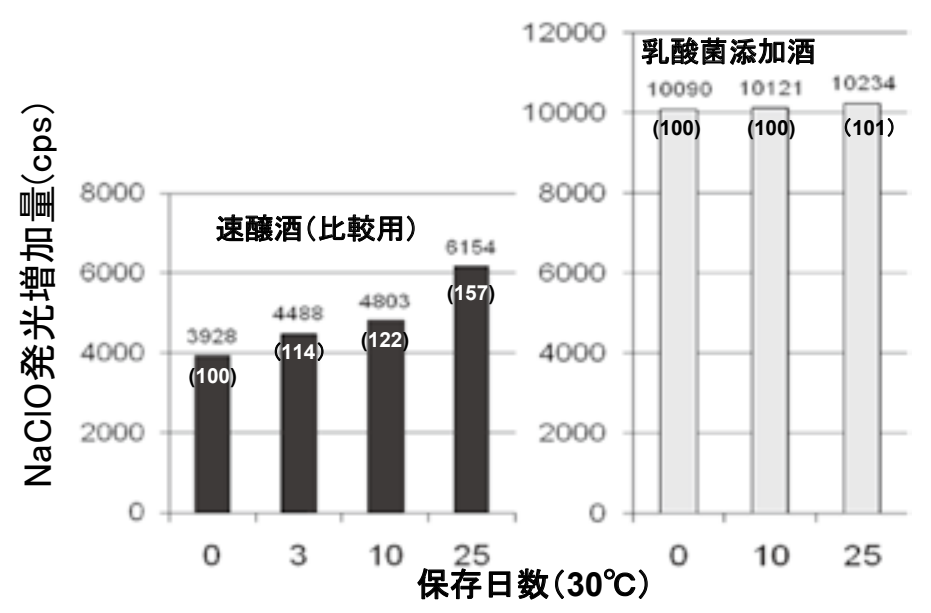

第 9 図 保存試験結果

（）内の数字は各酒の保存試験開始時を 100 とした相対值

一般成分 (日本酒度, アルコール分, 酸度, アミノ酸度) は 次のとおり

速醸酒(比較用) : + 1.9, $17.7 \%, 1.3,1.1$

乳酸菌添加酒 : + 3.3, 17.3\%, $1.5,1.2$

いことを確認できた。なお, $\mathrm{NaClO}$ 発光值には $\mathrm{pH}$ が大きく影響するため ${ }^{15)}$ ，製造履歴の異なる清酒の 比較には予め補正が必要であると考えており, 今回一 般成分に大きな差がないにも関わらず製造時の両酒間 の発光值に大きな違いがみられた要因について，本発 光が捉えている成分の絞り込みにより, 今後検討の必
要があると考えている。

常温にて蔵内で約半年貯蔵後, H22 秋の栃木県清酒 鑑評会「純米酒の部」に出品し, 暗番審査にて鑑定官 を含む専門家の方々からも良好な評価を受けることが できた。また老香の発生も全くなく「味広がりあり」 「旨味あり」「やわらかい」「若い」「きれい」の好まし 
いコメントの一方「苦い」「生酛？」「木香様」などの 厳しいコメントもいただき, 今後の造りや貯蔵熟成, 出荷流通管理に反映させていくつもりである。

\section{5. おわりに}

本研究を始めたきっかけは, 清酒の製造技術レベル 向上に貯蔵出荷管理技術が追いつけず，せっかく良質 の清酒が製造されたにも関わらず，最終の消費者に満 足ゆく品質レべルの製品が提供できていないものが多 くなってきているのではないかという疑問が出発点で あり，小規模の清酒製造メーカーに打いておろそかに なりがちな貯蔵出荷管理に, 客観的で簡易な評価法を 提案したいというものであった。その後, 化学発光と いう計測技術を用い研究を進めるに従い, 生酛系清酒 の抗酸化性の高さや，酸化し難い特性が徐々に見え始 め，これを何とか積極的に製造に取り入れることを考 え，今回紹介したように酸化劣化が生じ難いと考えら れる清酒製造法の提案にまで繋がったものである。

熟成と劣化は, 生理的に受け入れられない香味を除 き，そのほとんどが同一の変化を表と裏から捕らえて いると考えることができる。最終的に消費者が付加価 值を認めれば熟成であり，認めてもらえなければそれ は単なる劣化でしかなく客観的な数值での線引きが困 難である。しかし，清酒が国際的にも認められつつあ る中，貯蔵や流通中の変化の度合いについての客観的 な判断基準の構築は必要であると考えており, 最も優 れた検出器としての人間の官能評価を補完するため, 特定の熟成，劣化成分を測定する手法とともに，化学 発光法が網羅的な貯蔵出荷管理の一助になれば幸いと 考えている。

今回, 酸化劣化を生じ難くする要因として考えられ た抗酸化性の評価法については，現在，測定原理の異 なる多種多様な測定法が用いられている。それらの中 で，光検出法である ORAC (Oxygen Radical Absorbance Capacity） 法 ${ }^{18)}$ は国際的に最も広く用いられ標 準法として期待されており ${ }^{20)}$ ，米国農務省ではこの 方法で測定した多くの食品の抗酸化能データベースが 公開され，目標摂取単位も具体的数值で推奨されてい る。我々は, 清酒の ORAC 值についても測定を行っ て扔り, 予想通り生酛系清酒の数值が高い傾向を示す ことを確認し平成 22 年の醉造学会大会にて報告した 19)。平成 22 年 12 月には栃木の蔵元である宇都宮酒造
(株)（酒銘：四季桜）の生酛酒（新製品）のラベルに, 清酒としては初めて ORAC 值表示が行なわれ販売が 開始された。我々は, 本数值が食品としての ORAC 值とともに, 製品が酸化劣化に対してどの程度の酒質 安定性が担保できるのかの基準として発信できるので はないかと期待している。

乳酸菌添加による清酒製造法は, 決して新しい技術 ではないが,「酒質安定性」と「醸造用乳酸無添加」 という大きな特徵を有しており, 今後の清酒販路のさ らなるグローバル化や有機表示への対応も可能であり， 今後, 幅広い展開が期待できると考えている。また, 今回の実地試験で用いた乳酸菌添加酒母育成法は, 過 去の製造法を参考にした特殊な手法であるが，現在複 数の酒造メーカーにおいて, 通常の高温糖化後に培養 乳酸菌を添加し酸を生成させた後酵母を添加する簡易 で汎用性が期待できる育成法について検討を行ってお り，同様に抗酸化性の高い清酒が得られることを確認 している。

今後は, 製造ロットによる抗酸化性や酒質のばらつ き, 高い抗酸化性の要因の解明など, 残された課題の 解決, 沉用性の高い製造法の確立に向け検討を加えて いきたいと考えている。

〈栃木県産業技術センター〉

\section{参考文献}

1）大澤善次郎 : ケミルミネッセンス - 化学発光の 基礎·応用事例（丸善株式会社,東京)，(2003）

2）丹羽一樹：産総研計量標準報告, 6(1), 53-59 (2007)

3）䅨原昌司, 兀下伸二, 関圭吾, 齋藤高弘, 志賀 徹, 大谷敏郎：日食科工誌，50(7)，303-309 (2003)

4）齋藤高弘, 蘒原昌司, 野口良造, 志賀徹：生態 工学, 19(2), 103-109 (2007)

5）吉城由美子：農化, 73(12), 1283-1288（1999）

6）野村佳司，木曽邦明：醸協，98(6)，449-455 (2003)

7）野村佳司, 水野昭博, 木曽邦明：醉協, 99(7), 521-525 (2004)

8）野村佳司, 水野昭博, 木曽邦明: 䁔協, 100(2), 141-145（2005）

9）岡本竹己，佐々木隆宏：栃木県産業技術セン夕 一研究報告，6，56-58（2009） 
10）岡本竹己：第 95 回清酒製造技術セミナーテキ ス卜，日本醸造協会，46-51（2009）

11）岡本竹己, 小坂忠之, 齋藤高弘：平成 18 年度 日本醸造学会大会講演要旨集, p16（2006）

12）齋藤高弘, 高橋大輔, 穆原昌司, 大谷敏郎, 志 賀徹：生態工学, 18(3)，125-130（2006）

13) H.Kitagaki, M.Tsugawa : J.Biosci.Bioeng., 87 (3), 328-332 (1999)

14）溝口晴彦, 原昌道:醸協 105（3）, 124-138（2010）

15）山口貴之, 齋藤高弘, 岡本竹己, 佐々木隆浩,

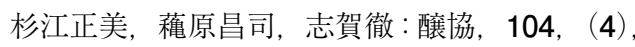
303-311 (2009)
16）江田鎌次朗：乳酸馴養最新清酒連醉法，菊姫ラ イブラリー3（日本評論社）,311-323（2006）

17）第 16 回（社）日本醸友会関東信越支部講演会 プログラム (2010)

18）沖智之：食品機能性評価マニュアル集第 II 集, 食品機能性評価支援センター編，79-86（2008）

19）星佳宏, 岡本竹己, 伊藤和子, 佐々木隆宏, 阿 部恭幸, 齋藤高弘: 平成 22 年度日本醸造学会 大会講演要旨集, p14（2010）

20）渡辺純, 沖智之, 竹林純, 山崎光司, 津志田藤 二郎：化学と生物, 47(4), 237-243（2009） 